\title{
Curcuma zanthorrhiza Extracts Induce G2/M Cell Cycle Arrest and Apoptosis in 4T1 and MCF-7 Human Breast Cancer Cells
}

\author{
Sari Haryanti ${ }^{1 *}$, Galuh Ratnawati ${ }^{1}$, Nuning Rahmawati ${ }^{1}$ \\ ${ }^{1}$ Medicinal Plant and Traditional Medicine Research and Development Centre, National Institute of Health Research \\ and Development Tawangmangu, Indonesia \\ *Corresponding Author. Email: sari.haryanti@gmail.com
}

\begin{abstract}
Curcuma zanthorrhiza Roxb., known as Javanese turmeric or temulawak in Indonesia, has been reported to have several biological activities, including anticarcinogenic effects. In this study, we aimed to evaluate the effects of temulawak rhizome extract on the cell viability, cell cycle distribution, apoptosis induction, and antimigratory effect of human breast cancer cell line. The rhizome powdre was macerated using ethanol $96 \%$ to obtain dry extract. The cell lines (MCF-7 and 4T1) were subjected to increasing doses of temulawak extract and cell viability was quantified by MTT assay. Cell cycle profile and apoptosis induction were done using flow cytometry assay. In vitro wound healing assay was performed on 4T1 cells to evaluate antimigratory effect. Temulawak extract inhibited the growth of MCF-7 and 4T1 cells with the IC50 value 46 and $37 \mu \mathrm{g} / \mathrm{ml}$ respectively. Temulawak extracts induced cell cycle arrest in G2/M phase and apoptosis in MCF-7 and 4T1 cells. The extract was not show anti-migration effect in wound healing assay. This study confirms the potential cytotoxic effects of temulawak in breast cancer cell line and could be developed as a potential chemopreventive agent.
\end{abstract}

Keywords: Curcuma zanthorrhiza, cell cycle, apoptosis

\section{INTRODUCTION}

Cancer continues to be the leading cause of mortality and morbidity throughout the world. Cancer incidence is suggested to increase by $70 \%$ over the next two decades. Several research findings indicate a disproportionate distribution of new cancer cases and deaths that accompany certain regions of the world, with poorer and lower-income countries [1]. Breast cancer is the most common cancer type in women and the second most common cancer in the world [2]. Breast cancer is a also heterogeneous disease. The individual's genetic in combination with histological types of tumors, molecular subtypes, and tumor microenvironment contribute to the development of the disease [3].

Breast cancer treatment for all subtypes ultimately leads to the development of resistance, and often leads to increased disease and death. Drug resistance is a general manifestation of cancer and is a major factor in the failure of chemotherapy. The underlying mechanism of chemoterapy resistance is poorly understood [4]. Genetic mutations in various proteins is thought to be one of the causes of chemoresistance. The mutations involve in cellular mechanisms such as cell cycle, apoptosis and cell adhesion. Targeting these mechanisms could improve the outcomes of cancer therapy. Recent developments are focused on combination therapy, by sensitizing cancer cells to chemotherapeutic agents. The sensitizing agent plays as inhibitors of chemoresistance target pathways, and is expected to solve the problems of chemoresistance [5].

The increasing problems related to drug resistance and drug toxicity have encoureged the investigation of new potential anticancer compounds from natural sources, including plants. It is estimated abaout $50 \%-60 \%$ of cancer patient in the United States use compounds of plants or nutrients as a complementary or substitution medicine. The application is commonly for single therapy or alongside with chemotherapy and/or radiation therapy. The evidences based research confirmed the anticancer activities of natural plants derived bioactive compounds. Many researches resulted in an increase of comprehensive compounds as a chemical and biological functional agent with constructive effect on human health [6].

Curcuma zanthorrhizza Roxb., also known as Java turmeric or temulawak in Indonesia, is a ginger-like plant belongs to Zingiberaceae family. Temulawak originates from Indonesia especially in Java island. It has been grown wild and cultivated in Thailand, Philippines, Sri Lanka and Malaysia [7]. Its rhizome is used in the countries of Southeast Asian for food and some medicinal purposes. Temulawak has been traditionally used to treat stomach disease, liver disorder, constipation, dysentery, diarrhea, fever, and hemorrhoids. Biological properties of temulawak have been studied by 
many researchers, including hepatoprotective, antinociceptive, antimicroba, and anticancer activities [8].

There is still limited information on the effect of temulawak on breast cancer with different subtypes. This present study investigated the cytotoxicity, cell cycle profile, apoptosis induction, and anti-migratory effects of temulawak rhizomes extracts on 4T1 and MCF-7 breast cancer cells. The 4T1 is a model of breast cancer cells isolated from spontaneous breast tumors in $\mathrm{BALB} / \mathrm{cfC} 3 \mathrm{H}$ mice[9]. The $4 \mathrm{~T} 1$ cells have no expression of estrogen and progesterone receptors, and also HER2. So it is suitable for the triple negative breast cancer subtype model $[10,11]$. The $4 \mathrm{~T} 1$ cells exhibit stage IV cancer malignancy and have metastatic ability to bones, lungs, liver, spleen and brain; so it serves as an execellent model for metastatic breast cancer reasearch [12,13]. While MCF-7 is commonly used as a model of breast cancer research because of its perfect sensitivity to hormones through the expression of estrogen and progesteron receptors [14].

\section{METHOD}

Temulawak rhizomes were obtained from Post Harvesting Laboratory and indentified by Plants Systematic laboratory, Medicinal Plant and Traditional Medicine Research and Development Centre Tawangmangu. Dried rhizomes were extracted using $96 \%$ ethanol for $3 \times 24 \mathrm{~h}$, filtered, and evaporated to obtain the dry extract. Dried extract was dissolved in DMSO (Sigma) and freshly diluted in culture medium before used.

The breast MCF-7 cancer cell line was obtained from the American Type Culture Collection (ATCC). The 4T1 cell lines were obtained from Cancer Chemoprevention Research Centre, Faculty of Pharmacy, Gadjah Mada University Yogyakarta. The 4T1 cell line was kindly given by Prof. Kawaichi, Nara Institute of Science and Technology (NAIST), Japan. Cells were maintained in incubator at $37^{\circ} \mathrm{C}$ with 5\% CO2 in tissue culture dish (Iwaki) with Dulbecco's Modified Eagle's medium (DMEM, Sigma) supplemented with $10 \%$ fetal bovine serum (Sigma), and $100 \mu \mathrm{g} / \mathrm{ml}$ penicillin-streptomycin (Sigma). Subsequent to $80 \%$ confluence, the cells were detached using $0.25 \%$ trypsinEDTA. The culture medium was replaced every 2 days.

Cell viability assay was done using the MTT method to determine the effect of temulawak extract on the viability of 4T1 and MCF-7 cancer cells, as previously described described [15]. Briefly, 10.000 cells/well were cultured in a 96-well plate for $24 \mathrm{~h}$ and fresh medium containing various concentrations of the extract $(0-500 \mu \mathrm{g} / \mathrm{ml})$ were added. Subsequent to $24 \mathrm{~h}$, the cultured medium was removed, and cells were washed with PBS (Sigma). MTT $0.5 \mathrm{mg} / \mathrm{ml}$ in the medium was added into each well and incubated for 3-4 hours. MTT reaction was stopped by the addition of SDS $10 \%$ in $\mathrm{HCl} 0.01 \mathrm{~N}$ and incubated overnight in the darkroom. The absorbance was measured using the ELISA reader at $\lambda 595$ $\mathrm{nm}$ (Biorad). Each treatment were carried out in triplicate. The absorbance data were provided as percent viability compared to untreated cells.
Wound healing assay was done to evaluate cell migration as previously described [16]. Briefly, 4T1 cancer cells were seeded into 24 -well plates for $24 \mathrm{~h}$. Cells were scratched using a yellow $200 \mu$ l sterile pipette tip. Cells were then treated with different concentrations of temulawak extract $(0,5,10$ and 15 $\mu \mathrm{g} / \mathrm{ml})$. Images were obtained from $0,18,24$, and $48 \mathrm{~h}$. The closure of the scratched wound was determined by dividing the area of the scratch compared with the untreated control group using imageJ software.

Cell cycle profiles and apoptotic induction was analysed using flow cytometry. Approximately 5x105 of 4T1 and MCF-7 cells/well were cultured in 6 well plates and incubated for 24 hours. Cells treated with temulawak extract for 18 hours. The treated and untreated cells were then trypsinized, washed in PBS, and centrifuged $500 \mathrm{rpm}$ for 5 minutes. To find out the distribution of cell cycle, cells were fixed with cold ethanol $70 \%$ for 30 minutes, washed with PBS, and centrifuged $500 \mathrm{rpm}$ for 5 minutes. Cells were then resuspended in the reagent containing $40 \mu \mathrm{g} / \mathrm{ml}$ propidium iodide (Sigma), $20 \mu \mathrm{g} / \mathrm{ml}$ RNAse (Roche) and $0.1 \%$ TritonX114 (Sigma). The mixture were incubated $15 \mathrm{~min}$ in the dark, and then subjected to BD Accuri C6 flow cytometer. To investigate the apoptosis induction, trypsinized cells were centrifuged $500 \mathrm{rpm}$ for 5 minutes. The apoptotic cells detection were using BD Annexin V FITC Assay kit and the mixture subjected to BD Accuri C6 flow cytometer.

A linear regression of concentration and \% cells viability using Excel MS Office2013 were used to calculate the IC50 value from MTT assay. The scratch area was quantified using ImageJ software and defined as cell migration area. Percent closure was further analyzed using ANOVA statistical analysis with $95 \%$ percent reliance. The data obtained from flow cytometer was analysed using BD Accuri C6 software..

\section{RESULTS AND DISCUSSION}

To evaluate the cytotoxicity of temulawak ethanolic extract on human breast cancer, the MCF-7 and 4T1 cells were cultured with various concentrations of extract for $24 \mathrm{~h}$. The cytotoxic activity was determined using the MTT assay. The results revelaed the inhibition of MCF-7 and 4T1 cells growth with the half maximal inhibitory concentration (IC50) values of $46 \mu \mathrm{g} / \mathrm{ml}$ and $37 \mu \mathrm{g} / \mathrm{ml}$ respectively.

a)
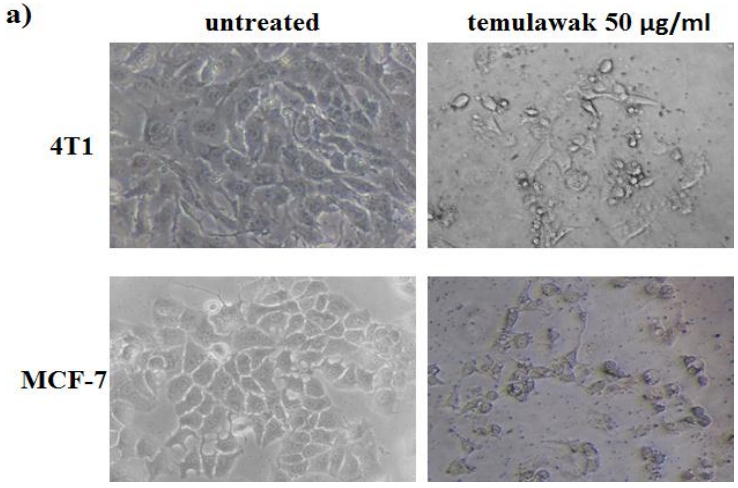
b)

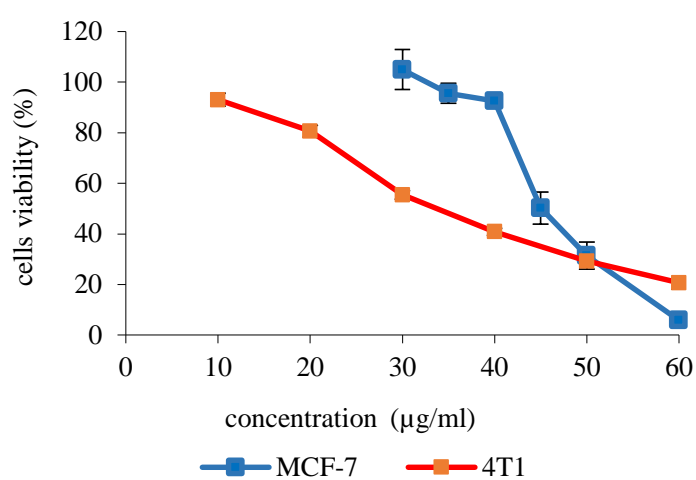

Figure 1. The MTT assay of cells treated with temulawak extract. a) The extract caused morphological changes on MCF-7 and 4T1 cells (magnification 200x); b) The graph of cells viability vs extract concentration

The cell cycle assay was determined by flow cytometry. As shown in Figure 2, temulawak extract $25 \mu \mathrm{g} / \mathrm{ml}$ treatment on MCF-7 cells resulted in the increasing of cell population in G2/M phase by $33,6 \%$ compared to untreated cells $(19,9 \%)$. In $4 \mathrm{~T} 1$ cells, temulawak $20 \mu \mathrm{g} / \mathrm{ml}$ treatment also resulted in the increasing of cell population in $\mathrm{G} 2 / \mathrm{M}$ phase cells by $48,1 \%$ compared to untreated cells $(26,8 \%)$. Based on this data, temulawak could induce G2/M cell cycle arrest in both 4T1 and MCF-7 cells. In the higher concentration, temulawak did not change cell cycle profile in both cells. However there were an increase in subG1 cell population.

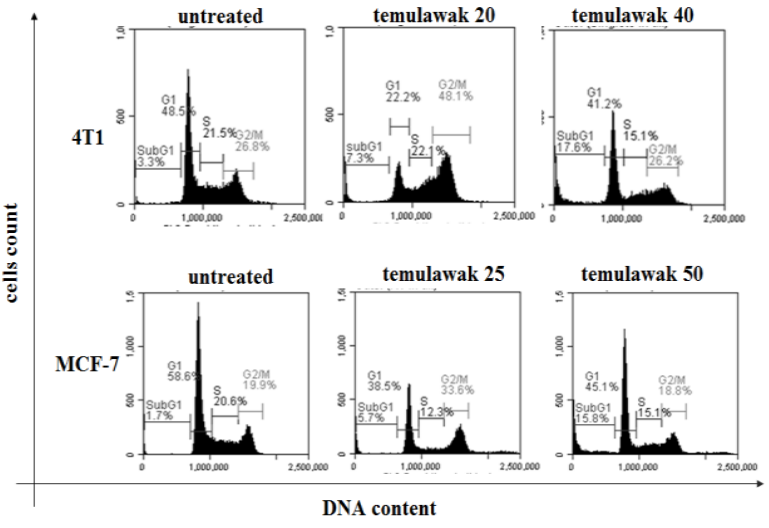

Figure 2. The flow cytometry histogram of cells cycle distribution treated by temulawak extract in 4T1 and MCF-7

To examine whether the inhibition of cells growth induced by temulawak dependent on apoptosis, temulawak-treated cells were analysed by Annexin V-FITC/PI double staining by flow cytometry. As shown in Fig. 3, in comparison to untreated cells, temulawak resulted in a significant increase on the number of apoptotic cells both in 4T1 and MCF-7.
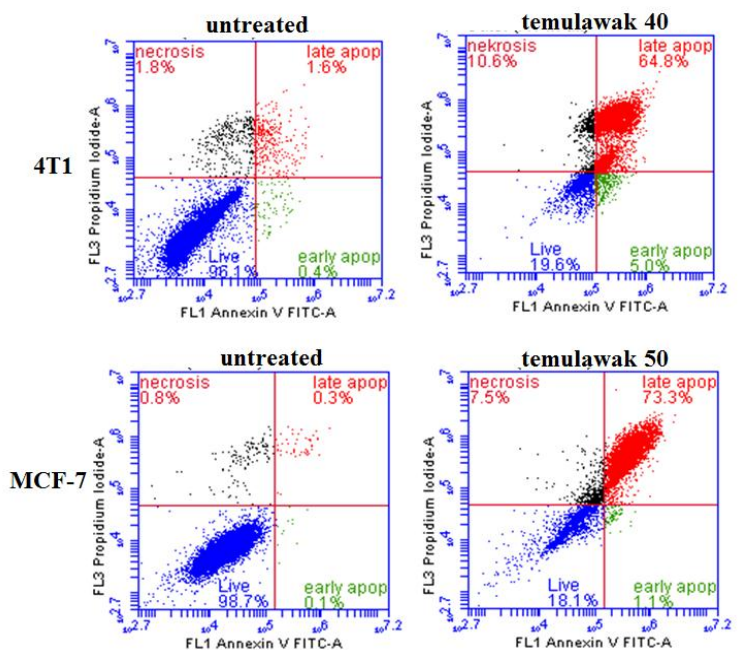

Figure 3 . The flow cytometry histogram of apoptosis cells induced by temulawak extract in $4 \mathrm{~T} 1$ and MCF-7

The next step is to determine the effect of temulawak extract $4 \mathrm{~T} 1$ cell migration by wound healing assay. This assay is a dynamic process that involving a complex movement of the missing cells. The observation of living cell motility is an effective method for measuring the rate of migration to the gap created by the original wound. The desired effect is when the wound area remains as large as possible, thus showing migration inhibitory effect [17]. The results analysis of wound healing assay was showed in Fig.4. The relative closure of the scratch showed that the extract did not inhibit $4 \mathrm{~T} 1$ cancer cell migration at the concentration of 5,10 , and $15 \mu \mathrm{g} / \mathrm{ml}$.

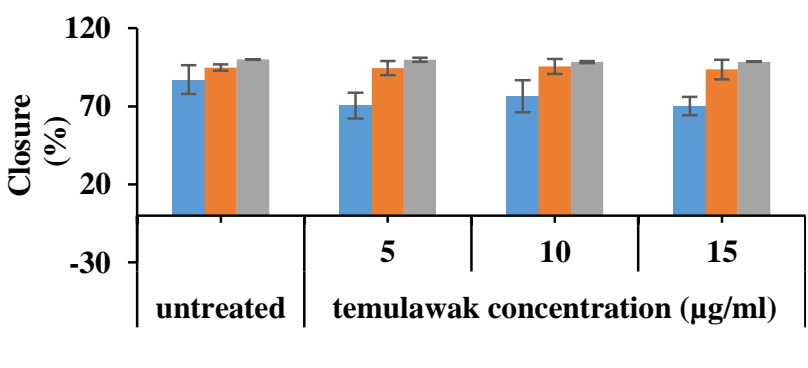

18 hours $\quad 24$ hours $\quad 48$ hours

Figure 4. The effect of temulawak extract on 4T1 cell migration wound healing assays. The chart showed the level of cell migration into the wound scratch quantified as a percentage of wound closure at 24 hours.

In the present study, the cytotoxic activity by which temulawak inhibits cells growth, changes cells cycle distribution, and induce cell death was investigated in breast 4T1 and MCF-7 cancer cell line. The results demonstrated that temulawak induced cancer cell death due to disruption of cell cycle, leading to cell cycle arrested in G2/M phase and apoptosis induction. Hence, temulawak may have potential use in the prevention and treatment of breast cancer. 
The main compounds contributing to the activities of temulawak are curcuminoids, including curcumin, demethoxycurcumin and bis-demethoxycurcumin. Curcumin is present as major component [18]. Hu et al., 2018, reported that curcumin significantly inhibited the proliferation of various breast cancer cell lines T47D, MCF-7, MDA-MB-231 and MDA-MB-468. The study of its mechanism of action showed that curcumin arrested cell cycle at the $\mathrm{G} 2 / \mathrm{M}$ phase. Curcumin decreased the expression of the CDC25 and CDC2 proteins, while increasing P21 expression. Curcumin also inhibited the phosphorylation of protein kinase B (Akt), decreased anti-apoptotic protein BCL2, promoted pro-apoptotic protein BAX, and cleavage of caspase 3, then inducing apoptosis of breast cancer cells [19]. Many research reported that besides curcuminoid, temulawak also contains sesquiterpenoid compund xanthorrizol. Cheah et al., 2006, reported that anthorrhizol has antiproliferative effects on MCF-7 cells by inducing apoptosis through the modulation of bcl-2, p53 and PARP-1 protein levels [20].

The accumulation evidence about cancer phenotypes has proposed that all cancers have in common six biological abilities acquired during multistep carcinogenesis: proliferative signaling sustainability, growth suppressors evasion, cell death resistance, replicative immortality, angiogenesis induction, and invasion-metastasis activation [21]. The cell cycle deregulation is a hallmark of normal cells transformation into tumor cells. Cell cycle plays importance role in tumorigenesis, and its inhibitors emerge as potential therapeutic drugs for the cancer treatment [22].

The imbalance of cell cycle regulation is one of the common target to combat cancer. Cell cycle checkpoints in response to DNA damages are important for the maintenance of the genomic stability and integrity in active proliferating cells [23]. Following the detection of DNA damage, cells will block cell cycle progression and activate cell cycle checkpoints [24]. Cell cycle checkpoints is a safeguard mechanisms that cells perform to correctly complete cell cycle phases, repair damage or eventually commit suicide in case damage is unrepairable [25]. Major cytotoxic agents will activate the intra-S-phase checkpoint to inhibit DNA synthesis, leading to apoptosis or cellular senescence [26]. Temulawak changes the cell cycle profile of MCF-7 and 4T1 cells. The increasing population cells in G2/M showed the evidence of cell cycle disorder leading to apoptosis induction.

Apoptosis is an autonomous process involving the activation, expression, and regulation of a wide range of genes. Apoptosis is then guiding to programed cell death to elliminate unwanted or abnormal cells in organisms and maintainance a stable internal circumference [27]. Many researches reported that targeting apoptosis is possibly the most successful for cancer treatment and also effective for all types of cancer. Two common strategies for apoptotic targeting therapies are activation of proapoptotic molecules and obstruct of antiapoptotic molecules (BCL2 family). Any stage in the apoptosis pathways can be targeted, however, there is no suggestion of which is the most effective. As more apoptosis-inducing chemotherapy are designed, the most effective targets will be specified [28]
The capability of temulawak to induce apoptosis was not accompanied by migration inhibitory effect. This inability is related to the effect of temulawak in inducing cell cycles arrest in the G2/M phase. Chu et al., 2018, reported that cellcycle progression and the migratory acquisition are found as independent processes but may be interconnected. The interconnection is through molecular pathways that control microtubule nucleation at centrosomes. Cell-cycle progression dramatically impacts the engraftment kinetics of breast cancer cells. Cell migration occurs with an elevated velocity and directionality during $\mathrm{S}-\mathrm{G} 2$-phase. Cells in this phase possess front-polarized centrosomes with augmented microtubule nucleation capacity [29]. This results suggest that temulawak extract could be used best in the early stage of carcinogenesis. The application of temulawak for cancer metastatis might be combined with the migratory inhibitor agent. Further research needed to develope temulawak as single agent or in ideal combination for cancer treatment effectively.

\section{CONCLUSION}

Taken together, our data showed that temulawak inhibit breast cancer cell growth by causing cell arrest at the G2/M phase. High doses of temulawak promote apoptosis and initiate programmed cell death. Meanwhile, in wound healing assay temulawak have no effect on cell migration. These findings may provide some new insights into temulawak effects and mechanisms in human breast cancers

\section{REFERENCES}

[1] McDaniel JT, Nuhu K, Ruiz J, Alorbi G. Social determinants of cancer incidence and mortality around the world: an ecological study. Glob Health Promot. 2019;26(1):41-49.

[2] Rivera-Franco MM, Leon-Rodriguez E. Delays in breast cancer detection and treatment in developing countries. Breast Cancer Basic Clin Res. 2018;12:117822341775267.

[3] Rodrigues- Peres RM, S. Carvalho B, Anurag M, Lei JT, Conz L, Gonçalves R, et al. Copy number alterations associated with clinical features in an underrepresented population with breast cancer. Mol Genet Genomic Med. 2019;7(7):e750.

[4] Lukong KE. Understanding breast cancer - The long and winding road. BBA Clin. 2017;7:64-77.

[5] Alimbetov D, Askarova S, Umbayev B, Davis T, Kipling D. Pharmacological targeting of cell cycle, apoptotic and cell adhesion signaling pathways implicated in chemoresistance of cancer cells. Int $\mathrm{J}$ Mol Sci. 2018;19(6):1690.

[6] Mollakhalili Meybodi N, Mortazavian AM, Bahadori Monfared A, Sohrabvandi S, Aghaei Meybodi F. Phytochemicals in cancer prevention: a review of the 
evidence. Iran J Cancer Prev. 2017; In Press(In Press). doi:10.17795/ijcp-7219.

[7] Oon SF, Nallappan M, Tee TT, Shohaimi S, Kassim NK, Sa'ariwijaya MSF, et al. Xanthorrhizol: a review of its pharmacological activities and anticancer properties. Cancer Cell Int. 2015;15:100.

[8] Kanase V, Khan F. An overview of medicinal value of curcuma species. Asian J Pharm Clin Res. 2018;11(12):40-45.

[9] DuPré SA, Redelman D, Hunter KW. The mouse mammary carcinoma 4T1: characterization of the cellular landscape of primary tumours and metastatic tumour foci. Int J Exp Pathol. 2007;88(5):351-360.

[10] Kaur P, Nagaraja GM, Zheng H, Gizachew D, Galukande M, Krishnan S, et al. A mouse model for triplenegative breast cancer tumor-initiating cells ( $\{\mathrm{TNBC}\}$ \{TICs\}) exhibits similar aggressive phenotype to the human disease. BMC Cancer. 2012;12(1):120.

[11] Sztalmachova M, Gumulec J, Raudenska M, Polanska H, Holubova M, Balvan J, et al. Molecular response of 4T1-induced mouse mammary tumours and healthy tissues to zinc treatment. Int $\mathbf{J}$ Oncol. 2015;46(4):1810-1818.

[12] Pulaski BA, Ostrand-Rosenberg S. Mouse 4T1 breast tumor model. Curr Protoc Immunol. 2001;20(2):1-20.

[13] Tao K, Fang M, Alroy J, Sahagian GG. Imagable 4T1 model for the study of late stage breast cancer. BMC Cancer. 2008;8(1):228.

[14] Holliday DL, Speirs V. Choosing the right cell line for breast cancer research. Breast Cancer Res. 2011;13(4):215-222.

[15] Riss TL, Moravec RA, Niles AL, Duellman S, Benink HA, Worzella TJ, et al. Cell Viability Assays. Eli Lilly \& Company and the National Center for Advancing Translational Sciences http://www.ncbi.nlm.nih.gov/pubmed/23805433. Accessed 19 March 2018.

[16] Jonkman JEN, Cathcart JA, Xu F, Bartolini ME, Amon JE, Stevens KM, et al. An introduction to the wound healing assay using live-cell microscopy. Cell Adh Migr. 2014;8(5):440-51.

[17] Liang C-C, Park AY, Guan J-L. In vitro scratch assay: a convenient and inexpensive method for analysis of cell migration in vitro. Nat Protoc. 2007;2(2):329-333.
[18] Rohman A, Sudjadi, Devi, Ramadhani D, Nugroho A. Analysis of Curcumin in Curcuma longa and Curcuma xanthorriza Using FTIR Spectroscopy and Chemometrics. Res J Med Plant. 2015;9(4):179-186.

[19] Hu S, Xu Y, Meng L, Huang L, Sun H. Curcumin inhibits proliferation and promotes apoptosis of breast cancer cells. Exp Ther Med. 2018;16(2):1266-1272.

[20] Cheah YH, Nordin FJ, Tee TT, Azimahtol HLP, Abdullah NR, Ismail Z. Antiproliferative property and apoptotic effect of xanthorrhizol on $\{$ MDA $\}-\{M B\}-231$ breast cancer cells. Anticancer Res. 2008;28(6A):36773689.

[21] Kato Y, Maeda T, Suzuki A, Baba Y. Cancer metabolism: New insights into classic characteristics. Jpn Dent Sci Rev. 2018;54(1):8-21.

[22] Bai J, Li Y, Zhang G. Cell cycle regulation and anticancer drug discovery. Cancer Biol Med. 2017;14(4):348-362.

[23] Dominguez-Brauer C, Thu KL, Mason JM, Blaser H, Bray MR, Mak TW. Targeting Mitosis in Cancer: Emerging Strategies. Mol Cell. 2015;60(4):524-536.

[24] Shaltiel IA, Krenning L, Bruinsma W, Medema RH. The same, only different - DNA damage checkpoints and their reversal throughout the cell cycle. J Cell Sci. 2015;128(4):607-620.

[25] Visconti R, Della Monica R, Grieco D. Cell cycle checkpoint in cancer: a therapeutically targetable doubleedged sword. J Exp Clin Cancer Res. 2016;35(1):153.

[26] Mills CC, Kolb EA, Sampson VB. Development of chemotherapy with cell-cycle inhibitors for adult and pediatric cancer therapy. Cancer Res. 2018;78(2):320-325.

[27] Chen L, Zeng Y, Zhou S-F. Role of Apoptosis in Cancer Resistance to Chemotherapy. In: Current Understanding of Apoptosis - Programmed Cell Death. 2018. InTech doi:10.5772/intechopen.80056.

[28] Pfeffer CM, Singh ATK. Apoptosis: A Target for Anticancer Therapy. Int J Mol Sci. 2018;19(2):448.

[29] Chu TLH, Connell M, Zhou L, He Z, Won J, Chen $\mathrm{H}$, et al. Cell Cycle-Dependent Tumor Engraftment and Migration Are Enabled by Aurora-A. Mol Cancer Res. 2018;16(1):16-31. 